\title{
THE PSYCHIATRIC OUTPATIENT'S FAMILY AS A SUPPORT SYSTEM
}

\section{Ms Emmerentia du Plessis}

MA (Psychiatric Community Nursing), North-West University, Potchefstroom Campus

Senior lecturer: School of Nursing Science, North-West University, Potchefstroom Campus

\author{
Prof. Dr. M Greeff \\ DCur (Psychiatric Nursing), RAU \\ Director: School of Nursing Science, North-West University, Potchefstroom Campus
}

\author{
Prof. Dr. MP Koen \\ DCur (Professional Nursing), RAU \\ Professor: School of Nursing Science, North-West University, Potchefstroom Campus
}

Key terms: psychiatric outpatients; family; support system; psychiatric community nursing; psychiatric community nurse; community-based mental health services; resource; mobilisation

\begin{abstract}
During 1998 the discharge of as many as possible psychiatric patients from long-term psychiatric hospitals in the North-West Province, in other words deinstitutionalisation, were planned (Roos, 1998). Greater responsibility was therefore placed on families with a psychiatric patient as family member. The researcher's experience as a psychiatric community nurse was that these families were often not empowered to cope with supporting their family member in the community. Psychiatric outpatients were consequently re-admitted and families became discouraged. The research aimed to investigate the perceptions of the patient and the family regarding the contribution of the family as a support system. A further aim was to formulate guidelines for the psychiatric community nurse to mobilise the family as a support system. A qualitative design was followed. Participants were identified by purposeful, voluntary sampling. Data gathering took place by conducting semi-structured interviews, which were transcribed and subjected to coding. The perceptions of both the patient and the family were that the family renders support regarding the patient's physical, psychological, social and spiritual dimensions. Conclusions regarding the patient, the family and the interaction between the patient and the family were formulated. Recommendations for nursing research, education and practice, including guidelines for the psychiatric community nurse to mobilise the family as a support system, were formulated.
\end{abstract}

*Throughout the article "he/him/his" also implies "she/her", and "patient" refers to "the psychiatric outpatient as a resident family member".

\section{OPSOMMING}

Gedurende 1998 is die ontslag van so veel moontlik psigiatriese pasiënte van langtermyn-psigiatriese hospitale in die Noordwes-Provinsie, met ander woorde deïnstitusionalisering, beplan (Roos, 1998). Groter verantwoordelikheid was op gesinne van psigiatriese pasiënte geplaas. Die navorser se ervaring as psigiatriese gemeenskapsverpleegkundige was dat hierdie gesinne heel dikwels nie bemagtig was om hulle gesinne in die gemeenskap te ondersteun nie. Psigiatriese buitepasiënte was gevolglik heropgeneem en gesinne het ' $n$ gevoel van moedeloosheid ervaar. Die navorsing was daarop gerig om die sienings van die pasiënt en die gesin ten opsigte van die bydrae van die gesin as ondersteuningstelsel te ondersoek. 'n Verdere doel was om riglyne om die gesin as ondersteuningstelsel te mobiliseer, vir die psigiatriese gemeenskapsverpleegkundige te formuleer. ' $n$ Kwalitatiewe ontwerp is gevolg. Deelnemers is deur middel van doelgerigte, vrywillige steekproefneming geïdentifiseer. Data-insameling het plaasgevind deur die voer van semi-gestruktureerde onderhoude. Die 
onderhoude is getranskribeer en gekodeer. Die sienings van beide die pasiënt en die gesin is dat die gesin ondersteuning bied ten opsigte van die pasiënt se fisieke, psigiese, sosiale en geestelike dimensies. Gevolgtrekkings is gemaak ten opsigte van die pasiënt, die gesin en die interaksie tussen die pasiënt en die gesin. Aanbevelings vir verpleegnavorsing, -onderrig en -praktyk, insluitende riglyne vir die psigiatriese gemeenskapsverpleegkundige om die gesin as ondersteuningstelsel te mobiliseer, is geformuleer.

\section{Introduction}

During 1998, in accordance with the National Government's primary health care approach (ANC, 1994:44), the North-West Provincial Government planned to discharge as many as possible psychiatric patients from long-term psychiatric hospitals to their families (Roos, 1998). This transfer in mental health services is called deinstitutionalisation (Rawlins, Williams \& Beck, 1993:902) and has an effect that greater responsibility is put on families with a psychiatric patient as a family member. They are expected to support the patient towards integration and normalisation in the community (Sands, 1991:9).

\section{BACKGROUND}

Deinstitutionalisation is the process that takes place when institutions and long-term institutionalisation are replaced by community-based mental health services and community support systems in order to promote the psychiatric outpatient's integration and normalisation in the community (Perko \& Kreigh, 1988:506; Rawlins, Williams \& Beck, 1993:902). One approach to deinstitusionalisation is to discharge large numbers of psychiatric outpatients, and primarily expect their families to support them in the community. The United States of America followed this approach, unfortunately without mobilising families to effectively carry out this responsibility (Hanson \& Rapp, 1992:182). Unprepared families were emotionally and financially drained and mentally ill patients were rejected and rendered unemployed and homeless (Wilson \& Kneisl, 1992:959; Weisburd, 1990:1245). Most of them experienced rejection and hopelessness (Taylor, 1994:43). In Britain deinstitutionalisation took place with more caution, as the possible isolation, rejection and neglect of patients by unprepared families were anticipated (Reed, 1984:83). A more successful approach was followed, namely that big psychiatric hospitals were replaced with smaller community based facilities, necessitating the development of a community based mental health care system (Culhane, 1996:25). In South Africa deinstitusionalisation was proposed as part of the attempt to correct fragmented and centralised mental health services (Uys, 1997:64; ANC, 1994:44). A primary health care approach was suggested, in which clinics, health centres and independent practitioners were the primary areas of first contact with the health system, in contrast with the hospital as first contact (ANC, 1994:19). The North-West Province planned to implement this approach by discharging as many as possible psychiatric patients from long-term psychiatric hospitals (Roos, 1998), as well as to increasingly treat psychiatric patients in the community.

Deinstitutionalisation necessitates that an effective community based mental health service be rendered, to support both the family and the patient. The psychiatric community nurse is a key role player in the community based mental health service. She is not only a member of the multi-professional team, but she also has first line contact with the psychiatric patient and his family (Koen, 1993:18; Hanson \& Rapp, 1992:195). Her unique qualities and skills enable her to mobilise the family as a support system. The mobilised family has the potential to provide the patient with material resources (Wellman, 1981:172), to give attention to his emotional and spiritual needs (Sewpaul, 1993:188) and to facilitate his social integration (Gottlieb \& Hall, 1981:186).

\section{PROBLEM STATEMENT}

The researcher, during her practice as a psychiatric community nurse in the Potchefstroom District of the North-West Province, observed that families and psychiatric patients experienced similar problems as in the USA and Britain. Families became despondent with their inability to cope with the responsibility to support the patient. Psychiatric patients on the other hand suffered the consequence of their families' in- 
ability to support them, and they were repeatedly being readmitted, which prevented them from living a fulfilled life as a valued community member.

\section{OBJECTIVES}

The problem and background information led the researcher to identify the following objectives for the research:

- to investigate the perceptions of the psychiatric outpatient as resident family member regarding his family's contribution as a support system;

- to investigate the perceptions of the family regarding their contribution as a support system; and

- to formulate guidelines for the psychiatric community nurse to mobilise the family as a support system.

\section{RESEARCH DESIGN}

A qualitative design was followed to explore and describe the perceptions of the psychiatric outpatient as a resident family member and that of the family respectively, regarding the family's contribution as a support system. Burns and Grove (1993:301) prescribes this design as the most appropriate design when the intention is to gain insight regarding a certain phenomenon as it occurs at a certain time, as in this case.

The research took place within the psychiatric community service of the Potchefstroom district in the North-West Province as context. The Potchefstroom district includes the communities of Potchefstroom, Ikageng, Promosa, Mohadin, Fochville and Kokosi. The psychiatric community service at that time rendered service to an average of 600 psychiatric outpatients per month, of which most were Black patients, followed by a smaller number of White and Coloured patients and a very small group of Asian patients. These patients were mainly diagnosed with schizophrenia, schizoaffective disorders, mood disorders, anxiety disorders and substance abuse. They were mostly from low and middle socio-economic groups, and their educational levels varied from low to high.
The researcher obtained permission from the Department of Health in the Potchefstroom district to conduct the research. As prescribed by Wilson (1993:245) and DENOSA (1998:3), the researcher informed these authorities of the research by making the research proposal available to them.

The population from which the sample for patients was taken was the population of psychiatric outpatients attending the psychiatric community service in the Potchefstroom district. The families of these psychiatric outpatients formed the population from which the second sample was drawn. Sampling took place through purposive, voluntary sampling. Inclusive criteria were set for both populations, and prospective participants were selected accordingly. Inclusive criteria for the psychiatric outpatients included that the patient should:

- be diagnosed with a mental illness;

- live with his family in the community for a minimum of at least three months;

- voluntarily receive treatment at the psychiatric community service;

- be apsychotic;

- have the cognitive and verbal ability to meaningfully answer questions during the interview;

- be willing to take part in the research;

- give permission that the semi-structured interview is recorded on audio-cassette; and

- be able to speak Afrikaans, English or be willing to communicate with the help of a interpreter.

Inclusive criteria for the families included that the family should:

- have a family member who is a psychiatric outpatient and is residing with them for a minimum of three months;

- be related to the psychiatric outpatient on grounds of consanguinity, marriage, adoption and/or a long-term relationship;

- consist of at least two members, excluding the psychiatric outpatient;

- have the cognitive and verbal ability to meaningfully answer questions during the interview;

- be willing to take part in the research;

- give permission that the semi-structured interview is recorded on audio-cassette; and

- be able to speak Afrikaans, English or be willing to communicate with the help of a interpreter. 
As suggested by DENOSA (1998:1) the researcher informed the prospective participants regarding the objectives and nature of the research, the data-gathering instrument and the behaviour that was expected from them, by providing them a letter and discussing the letter with them.

After voluntary, informed, written consent by the participants, the researcher arranged separate appointments with the patients and the families at a time and place convenient to them. Data-gathering took place by conducting semi-structured interviews with the patients, as well as semi-structured interviews with the families. The researcher utilised two separate interview schedules, one for interviewing the patient and one for interviewing the family. These interview schedules were based on a literature review and discussed with experts. The interview schedules were as follows:

Interview schedule for semi-structured interviews with the psychiatric outpatients:

- What do you see as support?

- What needs do you have regarding support from your family?

- How do you think can your family contribute to help you to stay in the community?

- In what do you need support from your family?

- What value do you attach to the support you receive from your family?

Interview schedule for semi-structured interviews with the families:

- What do you see as support?

- How do you think can you support your family member to stay in the community?

- What is your opinion on families' support to patients who are discharged to stay in the community with their families?

- In what does your family member need support?

- What influence does your support of the family member have on you as a family?

During the interviews the researcher utilised communication techniques, as described by Okun (1992:72) to explain, explore and clarify. Fieldnotes were taken after each interview, including observational notes, personal notes and methodological notes, as pre- scribed by Wilson (1993:222). Data saturation was reached after the researcher had interviewed seven patients and eight families. The interviews were recorded on audio-cassette and transcribed verbatim.

The researcher as well as an independent co-coder coded the transcripts. The coding took place according to a combination of the steps proposed by Giorgi (in Omery, 1983:57-58) and Tesch (in Creswell, 1994:154-155). After the independent coding the researcher and the co-coder reached consensus about the findings. Conclusions were formulated by synthesising the findings and the relevant literature and guidelines were set for nursing research, nursing education and nursing practice.

\section{TRUSTWORTHINESS}

Trustworthiness of the research was assured by following the strategies proposed by Guba (in Krefting, 1991:215-221). The principles underlying trustworthiness as indicated by Woods and Catanzaro (1988:136-137) as well as by Wilson (1993:56) were also integrated with the research. The specific techniques that were implemented in this research to achieve these strategies and criteria are set out in Table 1.

\section{ETHICAL ASPECTS}

General ethical principles were followed while conducting the research, including principles prescribed by DENOSA (1998), Dines (1995), Wilson (1993), and Polit and Hungler (1993).

The dignity of the participants were protected by means of obtaining voluntary, written, informed consent, by allowing them to ask questions during the interviews and by informing them that an expert was available for debriefing if necessary. Privacy, anonymity and confidentiality were ensured. A high standard of quality was obtained by ensuring that the researcher and supervisors were competent to conduct research, by obtaining permission from relevant authorities to conduct the research, by reporting to nurse research experts throughout the research, by thoroughly documenting the research and by acknowledging role players and contributors. 
Table 1: Trustworthiness

\begin{tabular}{|c|c|c|}
\hline CRITERIA & STRATEGY & TECHNIQUE \\
\hline Truth value & Credibility & $\begin{array}{l}\text { The researcher was involved in the research field as psychiatric } \\
\text { community nurse; } \\
\text { Triangulation was achieved by conducting a literature review, } \\
\text { presenting the research to experts throughout the process, } \\
\text { involving an independent co-coder during data-analysis and the } \\
\text { conducting of a pilot study; } \\
\text { Written agreement to participation in the research was obtained } \\
\text { from the participants; } \\
\text { Purposive, voluntary sampling was conducted. }\end{array}$ \\
\hline Applicability & Transferability & $\begin{array}{l}\text { Information regarding the participants and the context of the } \\
\text { research was densely described. }\end{array}$ \\
\hline Consistency & Dependability & $\begin{array}{l}\text { The research design and method, the context of the research as } \\
\text { well as the role of the researcher was densely described; } \\
\text { Inclusive criteria for purposive, voluntary sampling were set; } \\
\text { Field notes were recorded directly after conducting the } \\
\text { interviews. }\end{array}$ \\
\hline Neutrality & Confirmability & $\begin{array}{l}\text { Two psychiatric nursing specialists, experts in the fields of } \\
\text { psychiatric community nursing and nursing research, were } \\
\text { appointed as auditors of the research process; } \\
\text { Triangulation was achieved by a dense description of the } \\
\text { research process; } \\
\text { The researcher was in contact with the participants on a monthly } \\
\text { basis over a period of three years. }\end{array}$ \\
\hline
\end{tabular}

\section{RESULTS OF THE RESEARCH}

The perception of the patient spontaneously divided into four categories, namely support of his physical, psychological, social and spiritual dimensions, as portrayed in Table 2.

Table 2 indicates that the patient emphasised specifically four aspects regarding his family's support of his physical dimension (see Column A, Table 2), namely his physical needs, medication control, material resources and practical help.

It was found that he regarded his family as the primary provider of his physical needs. The following quotation gives an indication of this result: "They do everything for me. I get good food." Koldjeski (1993:64) confirms that the family does support the patient regarding the aforementioned needs. Rawlins 


\section{TABLE 2: Perceptions of the psychiatric outpatient regarding his family's contribution as a support system}

\begin{tabular}{|c|c|c|c|}
\hline $\begin{array}{l}\text { Column A } \\
\text { Perceptions regarding support of his } \\
\text { physical dimension }\end{array}$ & $\begin{array}{l}\text { Column B } \\
\text { Perceptions regarding support of his } \\
\text { psychological dimension }\end{array}$ & $\begin{array}{l}\text { Column C } \\
\text { Perceptions regarding support of his social } \\
\text { dimension }\end{array}$ & $\begin{array}{l}\text { Column D } \\
\text { Perceptions regarding support of his } \\
\text { spiritual dimension }\end{array}$ \\
\hline $\begin{array}{l}\text { The patient expects his family to provide in his } \\
\text { physical needs, including food and hygiene. } \\
\text { The patient's family reminds him to take the } \\
\text { prescribed psychiatric medication, or hand it to } \\
\text { him to take. } \\
\text { Regarding the patient's material needs he is } \\
\text { dependent on his family as the prim ary provider } \\
\text { of accommodation and money. } \\
\text { The family renders practical help to the patient } \\
\text { during times when he is not able to do tasks } \\
\text { because of the mental illness from which he } \\
\text { suffers. }\end{array}$ & $\begin{array}{l}\text { The patient has the need for his family to } \\
\text { acknowledge his human dignity. } \\
\text { The patient has the need of unconditional } \\
\text { acceptance by his family. } \\
\text { The patient has the need that his family develop } \\
\text { an understanding of his behaviour through } \\
\text { gaining knowledge of the mental illness he } \\
\text { suffers from. } \\
\text { When the family is available to the patient, he } \\
\text { experiences security. } \\
\text { The patient perceive his family as available } \\
\text { when: } \\
\text { - they converse with him; } \\
\text { - they spend time in silence with him; } \\
\text { - they provide him with the opportunity to } \\
\text { vent his feelings; } \\
\text { - they provide him with advice; } \\
\text { they show interest regarding the effect of } \\
\text { his mental illness on his abilities and } \\
\text { regarding his welfare; }\end{array}$ & $\begin{array}{l}\text { The patient has a need to be acknowledged as parent } \\
\text { and to guide his children, whilst he is unsure of their } \\
\text { love for him. } \\
\text { The patient has a need to be involved as a valued } \\
\text { family member. } \\
\text { The family encourages the patient to take part in } \\
\text { household activities. } \\
\text { The patient depends on the family for guidance } \\
\text { regarding correct social behaviour. } \\
\text { The patient perceives his family as a role model for } \\
\text { independent living in the community. } \\
\text { The patient expects his family to obtain work for him in } \\
\text { order for him to spend his time constructively and that } \\
\text { he feels useful. } \\
\text { The family encourages the patient to have social } \\
\text { contact with friends, although he sometimes prefers to } \\
\text { isolate himself. }\end{array}$ & $\begin{array}{l}\text { The patient practises religion with his } \\
\text { family. }\end{array}$ \\
\hline
\end{tabular}




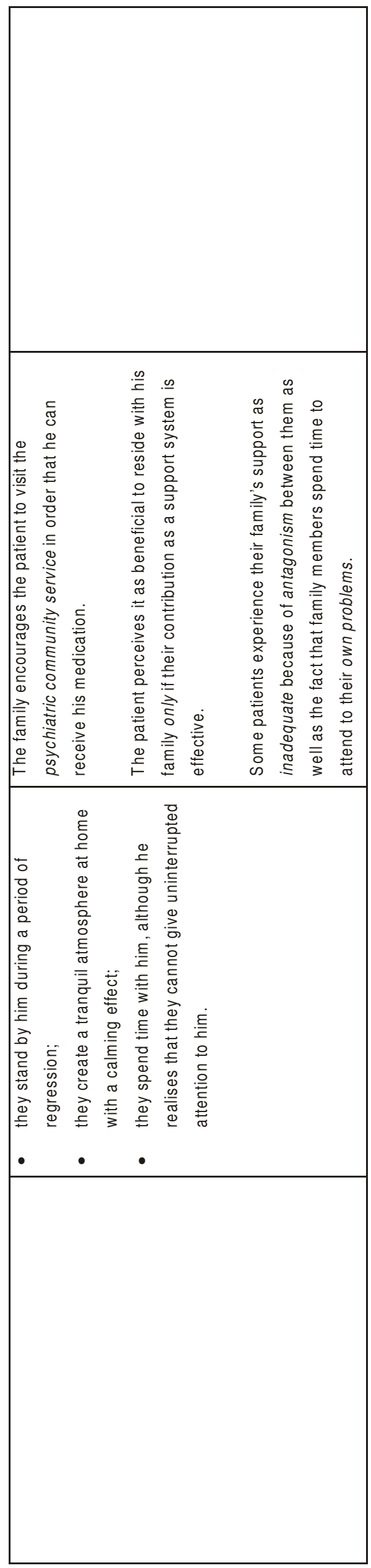

et al. (1993:9) further mention that the patient often displays behaviour that indicates that he is dependent on external structures, in this case the family, to provide in his needs.

The patient further mentioned that he was reminded by his family to take his prescribed psychiatric medication regularly. The following quotation illustrates this result: "Hulle sê ek moet my pille drink en goed. Ek moet elke dag my pille drink." (They say I must take my pills and things. I must take my pills everyday.). The family thus acts as an extension of one of the functions of the psychiatric community service, namely to monitor the appropriate use of psychiatric medication (Carson \& Holloway, 1996:81).

Additionally, the patient perceived himself as dependent of the family for material resources, specifically accommodation and money. He depended on his family for accommodation, as indicated by the following quotation: "Ek bly hier omdat ek hier bly. Omdat ek nie ... finansieel kan ek nie op my eie gaan bly nie". (I stay here because I stay here. Because I ... financially I can't stay on my own.). He also mostly depends on his family for an income, as evident from the following quote: "Kyk, ek werk op die oomblik nou nie. Al inkomste wat ek nou hier in die huis in is, ek is maar nou twee maande getroud, is mos nou maar die ouma en oupa s'n, en dan die kind se onderhoud". (Look, I don't have work at the moment. All income that I have in this house, I am married for two months only, is that of the grandmother and grandfather, and the child's maintenance.). Culhane (1996:25) as well as Carson and Holloway (1996:81) confirm these findings.

The patient was also of the opinion that his family rendered practical help when he was not able to do tasks himself. The following quotation confirms this result: "... as ek voel ek kan nou nie ry nie, dat sy nou vir my dit ook sal doen". (If I feel that I can't drive, that she will also do it for me.). Stein, Rappaport and Seidman (1995:351) agree that the family supports the patient in times when the patient experiences stress. Bond (1982:42) additionally mentions that practical help forms part of support.

Column B in Table 2 portrays the patient's perceptions regarding his family's support of his psychologi- 
cal dimension. The patient needed his family to acknowledge his human dignity and that they acted accordingly. The following quotation illustrates this result: "As jy wil uitgaan moet hulle jou laat uitgaan. Ek meen ek is " $n$ vrou van twee-en-dertig". (If I want to go out, they must allow me to go out. I mean, I am a woman of thirty-two.). The patient also experienced the need that his family accept him unconditionally in spite of the fact that he suffered from mental illness. He was of the opinion that understanding of the mental illness and related behaviour, brings along acceptance. The following quotations support these results: "Aanvaarding veral met my siekte". (Acceptance especially with my illness.). "Dat hulle my net sal verstaan". (That they will just understand me.). Gouws (1988) agrees that when the psychological needs relevant to acknowledgement, acceptance and understanding, as expressed by the patient, are provided, successful functioning and adaptation may be facilitated.

In relation to these results, the patient experienced security when his family is available to him, as set out in Table 2, Column B. When the family was available to the patient, he experienced that they care for him, and he feels less fearful and alone. These results are confirmed by the following: "Dit sal my laat voel iemand gee nog vir my om". (It will make me feel that someone still cares.). "Ek voel net nie alleen nie ... en in die aand nie bang nie". (I don't feel alone, and at night not scared.). Wilson and Kneisl (1992:150) confirm that a feeling of security is facilitated when the patient is supported emotionally.

The perceptions of the patient regarding the family's support of his social dimension (see Column C of Table 2) demonstrated that the patient had the need to function independently as a parent, worthy family member and member of the community. He simultaneously had the need of being encouraged towards active participation.

Regarding parenthood, he experienced the need to give guidance to his children and that his children demonstrate love and acknowledgement towards him, for example: "Dat ek eendag as my kind skool toe gaan, dat ek haar ook ondersteun en goed in die skool". (That I one day when my child goes to school that I support her in school.). He however experienced his children as aloof: "Ja, maar ek glo nie my kind is lief vir my nie. Ek glo nie. Ek weet nie”. (Yes, but I don't believe my child loves me. I don't believe so. I don't know.). Literature relating to this result could not be found.

The patient needed to be involved as worthy family member. He mentioned the need to be involved in family activities, and to feel part of the family. He experienced it as a loss if he was not included in family activities. The following quotations portray these results: "Ek gaan vang ' $n$ bietjie vis en so aan. Ek en my pa en my broer". (I go fishing and so on. Me and my father and my brother.). "My broers hulle het geen erkenning vir my vir so iets nie”. (My brothers don't have any acknowledgement for me in something like that.). These results relate in general to family members' needs to have power, and to experience cohesion within the family (Koldjeski, 1993:56; Nicholls \& Everett, 1986:70).

Furthermore, the patient was of the opinion that his family encouraged him to take part in household activities. The patient however mentioned that he did not always have the energy to conduct these activities, for example: "My ma wil hê ek moet haar in die huis help ... Ek kan nie my samewerking gee nie ... Alles wat ek doen is vir my ' $n$ las en dit is vir my veeleisend". (My mother wants me to help her in the home ... I can't give my co-operation ... everything that I do is a burden and taxing.). Related literature could not be found.

The patient depended on his family for guidance regarding correct social behaviour, and he viewed his family as a role model for independent living in the community. These results were indicative of the patient's need for guidance in order that he did not display unacceptable behaviour. He followed the example of his family regarding independent living within the safety that his family offers. The following quotations illustrate these results: "Wat is reg, wat is verkeerd en hoe jy moet wees". (What is right, what is wrong, and how you should be.). "Ja, kyk, die huishouding doen ek self. Hulle gee vir my die geld dan gaan koop ek die kruideniersware". (Yes, the household I do on my own. They give me the money and then I go and buy groceries.). Literature confirms that the family does serve as a group of reference and 
example through which the patient's independence could be enhanced (Wilson \& Kneisl, 1992:150; Sewpaul, 1993:188).

The patient's need to be independent was indicated. He would like to obtain work in order to spend his time constructively and to feel useful. He however perceived it as his family's responsibility to obtain a job on his behalf, for example: "Deur te kyk of daar nie miskien ' $n$ klein werkie vir my is nie wat ek kan doen nie". (To see if there isn't maybe a small job for me that I can do.). Literature that specifically supports this result could not be found.

Further results indicated that it was the patient's perception that his family encouraged him to socialise with family and friends, as well as to attend the psychiatric community service. The patient however sometimes chose to isolate himself, and needed their understanding, as is apparent in the following quotation: "... dat hulle net sal verstaan as ek nie wil gaan nie". (... that they will just understand if I don't want to go.). Stein et al. (1995:351) mention that the family encourages contact between the patient and the community.

Lastly it was found that the patient perceived it as beneficial to reside with his family only if their contribution as a support system was effective. While some patients experience their family's support as adequate, other patients indeed experience this support as inadequate. This perception develops especially from antagonism between the patient and his family, as well as when family members focus on their own problems. The following quotations illustrate these results: "They are looking after me very well. I appreciate that", "Ek is heeltemal antagonisties teenoor hulle". (I am totally antagonistic towards them.), "Hulle kan my nie verder help nie. My broer se drankprobleem is dit nog "n groter kopseer vir ons". (They can't help me any further. My brother's alcohol problem is a bigger headache for us.). Chamberlin and Rogers (1990:1241) report that psychiatric outpatients do need support from their families. Other authors add that inadequate support might be ascribed to the fact that families are not fully mobilised as support system of the patient (Haber, McMahon, Schurdy \& Sideleau, 1992:752; Hanson \& Rapp, 1992:186).
The last category (see Column D of Table 2) was the patient's perceptions regarding support of his spiritual dimension. The patient focuses on the social aspect of his spiritual dimension, namely that he practised religion together with his family. The following quote supports this result: "Sondag ons gaan almal nou kerk toe". (Sunday all of us we now go to church.). Literature referring to this result could not be found.

The family's perceptions regarding their support of the patient are portrayed in Columns A to $D$ in Table 3. During coding the same dimensions mentioned by the patient came to the fore.

Column A of Table 3 relates the family's perception regarding their support of the physical dimension of the patient. The family helped the patient, specifically by doing tasks with or for him, guided by his needs for help. Hanson and Rapp (1992:186) confirm that the family's willingness to help the patient stems from love and concern for the patient. A further result is that the family regards it as important to provide the patient with preferred food and to ensure that he takes his prescribed medication. It is further the perception of the family that they provide the patient with material resources, specifically accommodation and extra money, as confirmed by Sands (1991:278) and Culhane (1996:25). The research additionally shows that the family did their best to support the patient regarding his physical dimension, and that they often provided beyond their own resources. The following quotations illustrate these perceptions: "As hy iets vra of nodig het dan gee ons maar vir hom". (If he asks for or needs something then we give it to him.), "I will try and get ... he likes food. He likes very much nice food and good food. He likes to have chocolates".

Results regarding the family's support of the psychological dimension of the patient are conveyed in Column B of Table 3 . The family provided direct as well as facilitative support.

Direct support aims to stabilise the psychological dimension (Bond, 1986:145), in this case by providing understanding, availability, comfort and unconditional acceptance.

It seemed that the family perceived understanding toward the patient as an important aspect of support. 
Table 3: Perceptions of the family regarding their contribution as a support system

\begin{tabular}{|c|c|c|c|}
\hline $\begin{array}{l}\text { Column A } \\
\text { Perceptions regarding support of the } \\
\text { patient's physical dimension }\end{array}$ & $\begin{array}{l}\text { Column B } \\
\text { Perceptions regarding support of the } \\
\text { patient's psychological dimension }\end{array}$ & $\begin{array}{l}\text { Column C } \\
\text { Perceptions regarding support of the } \\
\text { patient's social dimension }\end{array}$ & $\begin{array}{l}\text { Column D } \\
\text { Perceptions regarding support of the } \\
\text { patient's spiritual dimension }\end{array}$ \\
\hline $\begin{array}{l}\text { The family helps the patient as best they can, } \\
\text { guided by his needs. } \\
\text { The family helps the patient by doing tasks for or } \\
\text { with him. } \\
\text { Physical needs of the patient: } \\
\text { - The family takes the patient's preferences } \\
\text { into account when providing in his need for } \\
\text { food; } \\
\text { The family attempts to have the patient take } \\
\text { prescribed psychiatric medication, in order } \\
\text { that the patient behave with dignity and may } \\
\text { be accepted by the community. } \\
\text { Material resources: } \\
\text { The family provides the patient with } \\
\text { accommodation as resident family member. } \\
\text { The family provides the patient with extra } \\
\text { money, despite their own limited income. }\end{array}$ & $\begin{array}{l}\text { The family provides the patient with direct } \\
\text { support by means of the following: } \\
\text { - The family attempts to have understanding } \\
\text { for the patient. } \\
\text { - The family dem onstrates a lack of } \\
\text { understanding of the patient's unacceptable } \\
\text { behaviour and therefore need information } \\
\text { regarding mental illness and the handling } \\
\text { thereof. } \\
\text { Understanding of the handling of the patient } \\
\text { develops through contact with the patient } \\
\text { over a long period of time. } \\
\text { When members of the family place } \\
\text { themselves in the position of the patient, } \\
\text { they develop an understanding of the } \\
\text { patient. } \\
\text { The family has the need that their family } \\
\text { display understanding towards the patient. } \\
\text { The family strives towards being available } \\
\text { for the patient by: } \\
\text { - being in conversation with him, } \\
\text { listening to him and giving him advice; } \\
\text { allowing him to maintain a certain }\end{array}$ & $\begin{array}{l}\text { The family encourages the patient's social } \\
\text { integration by: } \\
\text { - Acting as a role model regarding the } \\
\text { patient's communication with the } \\
\text { community. } \\
\text { - Acting as role model regarding acceptable } \\
\text { behaviour in the community. } \\
\text { - Attempting to increase the patient's } \\
\text { constructive behaviour. } \\
\text { - Involving the patient in its daily living. } \\
\text { The family protects the patient against emotional } \\
\text { and physical harm by: } \\
\text { - Attempting to know where he is at all times } \\
\text { in order for him not to disturb members of } \\
\text { the community. } \\
\text { - Explaining the patient's behaviour to the } \\
\text { community so that the community may have } \\
\text { insight into the patient and not harm him } \\
\text { when he displays unacceptable behaviour. } \\
\text { The family identifies resources in the community: }\end{array}$ & $\begin{array}{l}\text { The family involves the patient in practising its } \\
\text { religion. } \\
\text { The family plays a role in the development of the } \\
\text { patient's value system through setting guidelines } \\
\text { regarding acceptable behaviour in the } \\
\text { community. }\end{array}$ \\
\hline
\end{tabular}




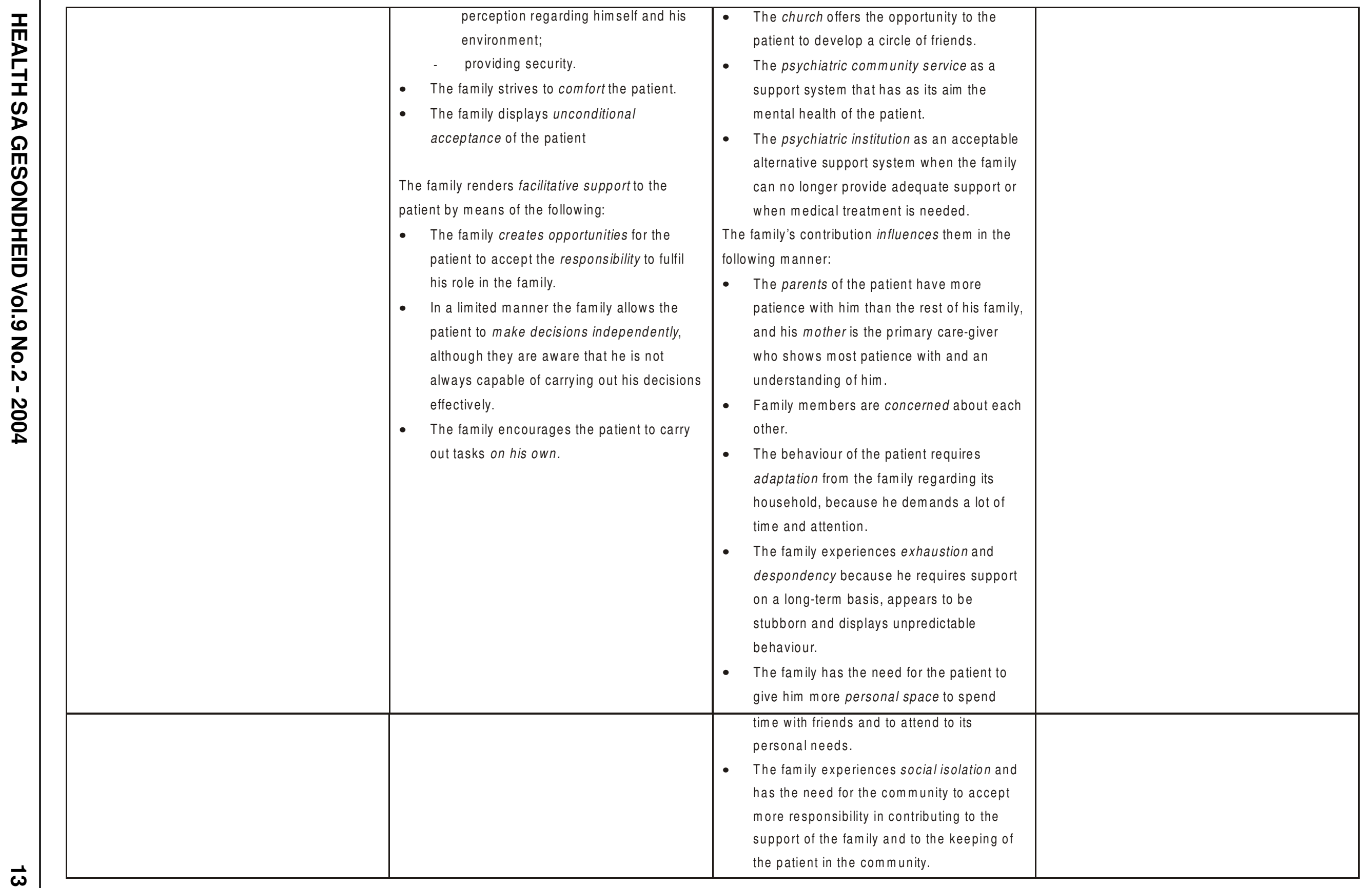


The following quotation confirms this finding: "Ek probeer verstaan dat sy verstand werk nie soos ons s'n nie". (I try to understand that his mind does not work like ours.). The family however indicated that they lack understanding regarding the patient's unacceptable behaviour. They therefore needed information regarding mental illness. This finding is illustrated by the following: " ... ' $n$ gesin moet ingelig wees oor wat dit is en dan ook hoe om so ' $n$ persoon te hanteer. Ouens moet defnitief daarin ook een of ander tipe van ' $n$ opleiding of inligtingsessie of so iets moet hulle aanbied". (.. a family must be informed regarding what it is and how to handle such a person. People must definitely present some or other training of information session regarding this.). Sands (1991:279) as well as Weisburd (1990:1245) mention that deinstitutionalisation in the USA had similar effects, namely that families perceived themselves as ignorant regarding mental illness, medication and how to handle inappropriate behaviour.

The family however also mention that they developed understanding towards the patient through contact with him over a long period of time, for example: "Maar ek moet sê ek het baie geleer. Ek het nie alles geweet nie. In die begin het ek hom nie so goed verstaan nie". (But I must say I have learnt a lot. I didn't know everything. In the beginning I did not understand him that well.). An additional way of gaining understanding is that the family put themselves in the position of the patient, for example: "What if I would have been disabled? If he thrown me away? How would l've felt? It's not right". This finding is not specifically referred to in the literature.

Furthermore, the family needed their next of kin to demonstrate understanding towards the patient. The following quotations indicate this result: "He is still there and he is an important part of the family", "Want die familie verstaan nie altyd nie". (Because the next of kin does not always understand.). Armstrong (1993:105) confirms that the family needs support.

Being available to the patient is also seen as part of direct support to the patient. The family strove to be available to the patient by listening to him and giving advice. They were also available to him when they allowed him to maintain certain perceptions regarding himself and his environment. This finding is confirmed by the following quotation: "Om maar net stil te bly en hom te laat praat. Want dit sal nie help om te argumenteer met hom nie, want jy gaan nêrens kom nie". (To keep quiet and to let him speak. Because it won't help to argue with him, because you wil get nowhere.). Koldjeski (1993:64) is of the opinion that family members could hereby create a climate of respect without negative evaluation, while several other authors (Stein et al., 1995:351, Wilson \& Kneisl, 1992:150) are of the opinion that feedback to the patient regarding his perceptions could facilitate personal growth.

Additional to being available, the family strove to provide security to the patient, to encourage the patient as well as to display unconditional acceptance towards the patient. The following quotation illustrates these findings: "Maar dan sal ek nou hier by hom kom sit terwyl hy huil en vir hom sê: 'Mammie is vir jou werklik lief'". (But then I will come and sit with him while he cries and say to him: "Mommy really loves you".). According to Sewpaul (1993:189) the patient may experience security and hope when he is supported in this manner.

The family also attempted to provide facilitative support when they encourage the patient to be independent. They expected him to fulfil his role in the family and to carry out tasks on his own. The patient, for example, had to take responsibility of certain important tasks in the household: " ... in die oggend gee sy vir hom ontbyt, as sy klaar gewas het dan maak sy vir hom toebroodjies". (In the morning she gives him (her husband) breakfast. After she has washed she prepares him some sandwiches.). The family also maintained the perception that in a limited manner, they allowed the patient to take independent decisions. They were aware that the patient did not always have the drive to carry out these decisions. The following quotations support this result: "Om hom toe te laat om, okei, die meeste van die tyd sy eie besluite te neem". (To allow him to, okay, most of the time to make his own decisions.). Literature specifically referring to these results could not be found. Nicholls and Everett (1986:70) mention in general that the family allocates power to a family member when they allow him to make decisions on his own.

Column C of Table 3 relates the family's perception regarding their support of the social dimension of the 
patient. The family placed emphasis on the patient's social integration, attempted to protect the patient against emotional and physical harm during his contact with the community and identified resources in the community. Further results indicate that the family is influenced in different ways by their support of the patient.

In their encouragement of the social integration of the patient, they acted as role models regarding communication with the community. They took the patient with them when visiting family: "I can take him to visit a family person or maybe I can take him to town". The family also acted as role models of socially acceptable behaviour by giving feedback to the patient regarding his behaviour. The following quotation supports this result: "Partykeer as hy nou kwaad doen dan sê ek nou so: Jy weet, ek is baie lief vir jou, maar as jy so maak, maak jy my hart baie seer'. (Sometimes when he behaves badly, then I tell him: "You know, I love you very much, but if you do that you hurt me a lot".). Additionally the family encouraged the patient to carry out constructive tasks, specifically household tasks and hobbies. They also encouraged him to obtain a job, although they realised that his ability to concentrate and his motivation to work might be low, as well as that stigmatisation by the community might make if difficult for him to obtain a job. The following quotations illustrate this result: "Doen 'n takie. Voel jy het iets gedoen". (Do a task. Feel you have done something.). "Maar waar kry jy iemand wat ek kan sê: 'Help hom en verdra hom'?". (But where do you find someone that I can say: "Help him and tolerate him"?). The family also attempted to involve the patient in their daily living, to demonstrate that they value him and that they would like to keep him in the community: "He mustn't feel left out, basically".

Several authors (Sewpaul, 1993:188; Stein et al. 1995:351) confirm that the family plays an important role in the social integration of the patient. Johnson (1993:17) specifically mentions that when the family facilitates constructive behaviour they contribute to the patient's preservation in the community. Stein et al. (1995:351) also mention that the family facilitates the patient's involvement in interpersonal relationships when they involve him in their daily living.
The family furthermore viewed it as important to protect the patient against possible emotional and physical harm in the community. One the one hand they were aware of the patient's unpredictable behaviour, and on the other hand they viewed the community as uninformed regarding handling the patient's behaviour. The family thus attempted to know where the patient was at all times, and to explain the patient's behaviour to the community. They did this so that the community might have insight and not harm the patient. The following quotation relates to these results: "Dan sê ek vir hulle: 'As julle hom sien en hy vloek julle, want hy vloek ons dan, moet hom nie slaan of hom seermaak nie. Want hy doen dit nie aspris nie. Help hom'". (Then I tell them: "If you see him and he curses you, because he curses us, don't hit him or harm him. Because he doesn't do it on purpose. Help him”.). Fawcett (1993:10) confirms that it is one of the functions of the family to protect its members from harm.

An extension of this support was that the family identified various resources of support for the patient. They specifically viewed the church as a resource that provided the opportunity for the patient to build a circle of friends. They also identified and utilised the psychiatric community service and psychiatric institutions as resources, especially when they needed professional help: "Psigiatriese behandeling. Baie daarvan. lemand teenoor wie hy kan uitpraat. Sonder om terug te hou. lemand wat sal verstaan en vir hom kan raad gee". (Psychiatric treatment. Lots of it. Someone with whom he can talk his heart out. Without holding back. Someone who will understand and who would be able to give him advice.). Hanson and Rapp (1992:192) and Weisburd (1990:1245) agree with these results, and add that families usually experience these services as inadequate.

Further results indicated that supporting the patient regarding his social dimension influences the family. It seemed that the roles of the family members were influenced, and that the individual members might experience social isolation, exhaustion, despondency, concern for each other and a need for more personal space. The following quotations demonstrate these results: "Maar ons twee het mak geaardheid vir haar, jy weet? Maar haar suster en ander het nie". (But us two have patience with her, you know? But her sister and others do not have.), "Jy moet baie aanpassings 
maak. Jy moet hom verstaan as hy snaaks optree". (You must adapt a lot. You must understand him when he behaves odd.), "En my pa is alewig soos ' $n$ wurm is hy in my lewe. En hy wil alewig weet wat doen ek, hoekom doen ek dit ... Ek meen dit het mos eintlik niks met hom te doen nie. Dit is my privaat lewe". (And my father is always like a worm, is he in my life. And he always wants to know what I am doing, why am I doing it ... I mean it does not have anything to do with him. It is my private life.). Weisburd (1990:1245) and Sands (1991:278) confirm that the family may experience exhaustion and despondency in their support of the patient.

The last identified category is the family's perception of their support of the spiritual dimension of the patient. This category is portrayed in Column D of Table 3. The family, regardless of their faith, focused on practising religion together with the patient. The family was aware of the patient's religious needs and provided him with opportunities to pray with them, to read from the Scriptures and to join them in public worship. Furthermore, the family played a role in the development of the patient's value system through setting guidelines regarding acceptable behaviour in the community. Quotations that confirm these results are the following: "Ja, his religious needs. He needs, I give him the Bible to read every morning ... When it's time to pray ...", "Soos byvoorbeeld, hy is baie lief vir die kerk. Hy is baie lief vir die Here Jesus. Want hy het toe hy jonk was tot bekering gekom. En dan wil hy partykeer Sondagaande saam met ons kerk toe gaan". (For example, he loves the church. He loves the Lord Jesus. Because he converted when he was young. And then sometimes he wants to go to church with us on Sunday evenings.). Koldjeski (1993:56) confirms that the family focuses on the enhancement of the patient's spiritual well-being. Sewpaul (1993:190) and L'Abate, Ganahl and Hansen (1986:25) additionally regard the development of a value system by the family, as indicated in the results, as important.

\section{CONCLUSIONS}

Conclusions were formulated from the results and the relevant literature, regarding the family, the patient as well as the interaction between the patient and the family.
The patient maintained an over-dependent attitude towards his family. This attitude limited his independence, whilst he nevertheless has an inner need to be viewed as an independent person and to be acknowledged as a dignified family member. The patient thereby limited his adaptation in the community.

Similar to the patient's perceptions, the family viewed the patient as dependent on them to fulfil his needs. The family assumed an over-responsible attitude towards the patient. The culminating effect was that the family experienced frustration, despondency, financial draining and social isolation. The family therefore identified resources in the community which they viewed as possible sources of support. However, the family's perception was that these resources were not supportive and were unavailable, which in turn enhanced their experience of despondency and isolation.

It was further concluded that the attitudes of the patient and the family as well as their vague and indirect communication led to a less involved relationship between them. This had the effect that their sense of purpose, their vision and their hope decreased.

\section{LIMITATIONS OF THE RESEARCH}

The following limitations could be identified:

- The sample of family members mainly included families in which the patient was a child or parent. Information regarding families in which the patient was a spouse was thus limited.

- Although various cultural groups were represented in the samples, specific cultural perceptions regarding mental illness, mental health and support were not investigated.

This information might have enriched the research.

\section{RECOMMENDATIONS}

The results and conclusions guided the researcher in making recommendations regarding research, education and practice in nursing. It is important that further nursing research focus on investigating a model for effective deinstitutionalisation, preparing a patient for deinstitutionalisation and/or the implications of mental illness for the patient's children and/or spouse. 
Nursing education should include the guidelines regarding mobilisation of the family as a support system in the basic and advanced courses in nursing. In-service training in primary health care settings should focus on outreach, continuity in support of the family and the patient, mental health education, culture-sensitive nursing and building trust relationships with the family and the patient. Recommendations for nursing practice are made in the form of guidelines for the psychiatric community nurse to mobilise the family as a support system.

\section{Guidelines for the psychiatric community nurse to mobilise the family as a support system}

The guidelines form a therapeutic process and may therefore be regarded as interdependent.

\section{Guideline 1: Facilitating shifts in the per- ceptions of the patient and his family}

This is essential in making the patient and the family aware of their respective over-dependent and overinvolved attitudes. This facilitation starts when the psychiatric community nurse forms a therapeutic relationship with the patient and his family. This creates the opportunity for the psychiatric community nurse to establish the family's readiness to take part in the therapeutic process. The objective reality, namely the nature of the mental illness and the characteristics of the family, could also be established. The therapeutic relationship could also facilitate the family members' commitment towards each other and the therapeutic process.

The psychiatric community nurse, alongside with the patient and the family, should then investigate the perceptions of the patient and his family regarding the potential of the patient to behave independently as well as regarding the family's contribution as a support system. This creates awareness amongst the patient and his family regarding their perceptions, and they are therefore able to compare these perceptions with the objective reality. Covey (1994:32) explains that the objective reality is composed of the existence of unchanging principles, for example, the symptoms and signs of mental illness. The psychiatric community nurse should reflect the objective reality to the patient and the family. Shifts in the patient and the fami- ly's perceptions are thereby facilitated. This process may be painful for them, thus the psychiatric community nurse should exhibit commitment, patience, empathy and perseverance.

The shifts in perceptions lead to changes in attitudes (Covey, 1994:28). The patient and the family are thereby prepared to change their respective over-dependent and over-responsible attitudes and to develop realistic expectations of themselves and of each other.

\section{Guideline 2: Facilitating a more involved relationship between the patient and his family}

The psychiatric community nurse should facilitate a more involved relationship between the patient and the family by encouraging effective communication. This entails the facilitation of trust, listening skills and communication of direct and clear messages. The psychiatric community nurse should be aware of the limiting effect that the patient's mental illness has on effective communication and the potential to have involved relationships, and attempt to enhance this potential.

By following the first two guidelines the psychiatric community nurse activates the family as a support system.

\section{Guideline 3: Facilitation of negotiation be- tween the patient and his family regarding the development of a synergistic package of support}

Negotiation between the patient and the family further mobilises the family to support the patient in the most relevant and mutually beneficial manner possible. During the process of negotiation the psychiatric community nurse should guard the interests of both the patient and the family. She encourages the patient to disclose his needs to his family, thereby enabling them to support him appropriately. The family's needs should also be addressed. The mobilisation of a support network, comprising the family's next of kin, support groups, the church, the psychiatric community service and the psychiatric institution, may serve the family's needs.

Guideline 3 concludes the mobilisation of the family as 
a support system.

\section{Guideline 4: Facilitation of a community- based mental health service of high qual- ity}

The community-based mental health service should focus on the mobilisation of the family as a support system. The psychiatric community nurse is in a position to influence the service in such a manner that this requirement is met. Her role should therefore includes the following:

- ensuring that individual, family, group and crisis therapy are available to the patient and the family;

- facilitating psychosocial rehabilitation services;

- facilitating relevant and responsible pharmacological services;

- facilitating the availability of financial advice;

- promoting continuity in the service;

- facilitating community involvement; and

- facilitating role players' skills to mobilise the family as a support system.

\section{SUMMARY}

Deinstitutionalisation of psychiatric patients is increasing in the North-West Province. Ensuring the stay of the psychiatric outpatient in the community is therefore an increasingly urgent issue in the mental health sector and needs to be addressed. The mobilisation of the family as a support system presents an opportunity to address this issue. The guidelines for the psychiatric community nurse to mobilise the family may therefore be viewed as important and valuable.

\section{BIBLIOGRAPHY}

ANC (African National Congress) 1994: The national health plan for South Africa. Lesotho: Bahr.

ARMSTRONG, E 1993: Mental health - a primary care perspective. (In: Trent, DR \& Reed, C eds 1993: Promotion of mental health. Avebury: Aldershot, pp 105-112).

BOND, M 1982: Do you care about your colleagues? Nursing Mirror, October, 155(16):42-44.

BOND, M 1986: Stress and self-awareness: A guide for nurses. London: Heinemann Nursing.

BURNS, N \& GROVE, SK 1993: The practice of nursing research; $2^{\text {nd }}$ ed. Philadelphia: Saunders.
CARSON, J \& HOLLOWAY, F 1996: Interventions with long-term clients. (In: Watkins, M; Hervey, N; Carson, J \& Ritter, S eds 1996: Collaborative community mental health care. London: Arnolk, pp 160-179).

CHAMBERLIN, J \& ROGERS, JA 1990: Planning a community-based mental health system: Perspective of service recipients. American Psychologist, 45(11):1241-1244.

COVEY, SR 1994: The seven habits of highly effective people. London: Simon \& Schuster.

CRESWELL, JW 1994: Research design: qualitative and quantitative approaches. Thousand Oaks: Sage.

CULHANE, M 1996: Integrating hospital and community services (In: Watkins, M; Hervey, N; Carson, J \& Ritter, S eds 1996: Collaborative community mental health care. London: Arnolk, pp 25-40).

DENOSA (Democratic Nursing Organisation of South Africa) 1998: Letter to university nursing science departments, nursing colleges, technikons and nursing schools regarding ethical standards for nurse researchers. 5 March1998. Pretoria: DENOSA.

DINES, A 1995: An ethical perspective-Nursing research. (In: Tingle, J \& Cribb, A eds 1995: Nursing law and ethics. London: Blackwell Science, pp 248-260).

FAWCETT, CS 1993: The contemporary family. (In: Fawcett, CS ed. 1993: Family psychiatric nursing. London: Mosby. pp 3-8).

GOTTLIEB, BH \& HALL, A 1981: Social networks and the utilization of preventive mental health services. (In: Price, RH; Kettere, RF; Bader, BC \& Monahan, J eds 1981: Prevention in mental health: Research, policy and practice. London: Sage, pp 167-194).

GOUWS, LA 1988: Realiteitsterapie. Unpublished.

HABER, J; MCMAHON, A; SCHURDY, SM \& SIDELEAU, BF eds 1992: Comprehensive psychiatric nursing. New York: McGrawHill.

HANSON, JG \& RAPP, CA 1992: Families' perspective of community mental health programmes for their relatives with a severe mental illness. Community Mental Health Journal, 28(3):181-195.

JOHNSON, DW 1993: Reaching out: Interpersonal effectiveness and self-actualization; $5^{\text {th }}$ edition. London: Allyn \& Bacon.

KOEN, MP 1993: ' $n$ Personeelontwikkelingsmodel vir psigiatriese verpleegkundiges. Auckland Park: Rand Afrikaans University. (Unpublished DCur thesis).

KOLDJESKI, D 1993: Family mental health. (In: Fawcett, CS ed. 1993: Family psychiatric nursing. London: Mosby, pp 45-77).

KREFTING, L 1991: Rigor in qualitative research: The assessment of trustworthiness. The American Journal of Occupational Therapy, 45(3):214-222.

L'ABATE, L; GANAHL, G \& HANSEN, JC 1986: Methods of family therapy. Englewoord Cliffs: Prentice Hall.

NICHOLLS, WC \& EVERETT, CA 1986: Systematic family therapy: An integrative approach. New York: Guilford.

OKUN, BF 1992: Effective helping; $4^{\text {th }}$ ed. Pacific Grove, CA: Brooks/ 
Cole.

OMERY, A 1983: Phenomenology: A method for nursing research.

Advances in Nursing Science, 5(2):49-63.

PERKO, JE \& KREIGH, HZ 1988: Psychiatric and mental health nursing; $3^{\text {rd }}$ ed. East Norwalk: Prentice-Hall.

POLIT, DF \& HUNGLER, BP 1993: Essentials of nursing research: Method, appraisal and utilisation; $3^{\text {rd }}$ ed. Philadelphia: Lippincott.

RAWLINS, RP; WILLIAMS, SR \& BECK, CK 1993: Mental healthpsychiatric nursing. A holistic life-cycle approach; $3^{\text {rd }}$ ed. St Louis: Mosby.

REED, J 1984: The elements of an ideal service: the clinical view. (In: Reed, J \& Lomas, G eds 1984: Psychiatric services in the community. London: Croom/Helm, pp 77-90).

ROOS, W 1998: Letter to district managers and assistant directors of primary health care, North-West Province, 21 January 1998. Klerksdorp. (Original copy in possession of the researcher).

SANDS, RG 1991: Clinical social work practice in community mental health. New York: MacMillan.

SEWPAUL, V 1993: The family as a focus of intervention for the prevention of mental disorder: An empowerment approach. Social Work/Maatskaplike Werk, 29(3):188-198.

STEIN, CH; RAPPAPORT, J \& SEIDMAN, E 1995: Assessing the social networks of people with psychiatric disability from multiple perspectives. Community Mental Health Journal, 31(4):351-367. TAYLOR, CM 1994: Essentials of psychiatric nursing; $14^{\text {th }}$ ed. St. Louis: Mosby. UYS, LR 1997: Mental health care in the health-care system. (In: Uys, L. \& Middleton, L. eds 1997: Mental health nursing: A South African perspective; $3^{\text {rd }}$ ed. Kenwyn: Juta, pp 63-75).

WEISBURD, DE 1990: Planning a community-based mental health system: perspective of a family member. American Psychologist, 45(11):1245-1248.

WELLMAN, B 1981: Applying network analysis to the study of support. (In: Gottlieb, BH ed. 1981: Social networks and social support. London: Sage, pp 117-2000).

WILSON, HS 1993: Introducing research in nursing; $2^{\text {nd }}$ ed. New York: Addison-Wesley. WILSON, HS \& KNEISL, CR 1992: Psychiatric nursing; $4^{\text {th }}$ ed. New York: Addison-Wesley.

WOODS, NF \& CATANZARO, M 1988: Nursing research: theory and practice. St. Louis: Mosby. 